\title{
Maladministration in the Public Service: Should Government Officials be Responsible for their Decisions?
}

\author{
Maulida Zulia Irmajayanti, Totok Sudaryanto, Antikowati \\ Faculty of Law, University of Jember (UNEJ) \\ maulidaazulia@gmail.com
}

\begin{abstract}
The concept of the welfare state upholds the existence of the legal system under the premise of legal certainty and the protection of basic human rights. Paragraph IV of the 1945 Constitution of the Republic of Indonesia emphasizes the existence of "state obligations" and "the government duty" to protect and serve all public interest. The normative basis of the Constitution was translated as the national principle to embody the public services. The Public Service Law Number 25 of 2009 is a formulation of legal certainty. However, the main problem that occurs in the public services is maladministration in bureaucracy. It is important to build interpretations of the authority attached to the bureaucratic system or on subjects who become government officials. By analyzing the Constitution, this article states that the government official dimensions must be considered as an interrelated issue, so that the articulate practice must be seen as inherent social conditions.
\end{abstract}

Keywords: Responsibility, Government Officials, Maladministration.

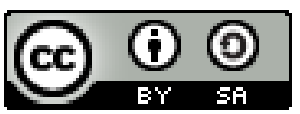

Copyright $\odot 2021$ by Author(s)

This work is licensed under a Creative Commons Attribution-ShareAlike 4.0 International License. All writings published in this journal are personal views of the authors and do not represent the views of this journal and the author's affiliated institutions.

\section{HOW TO CITE:}

Irmajayanti, Maulida Z \& Totok Sudaryanto et al. "Maladministration in the Public Service: Should Government Officials be Responsible for their Decisions?" (2021) l:1 Contemporary Sociological Issues 71-85.

$\begin{array}{llll}\text { Submitted } & \text { :October 30, 2020 } & \text { Accepted } & \text { :January 2, 2021 } \\ \text { Revised } & \text { :December 25, } 2020 & \text { Publish } & \text { : February 5, 2021 }\end{array}$




\section{INTRODUCTION}

Responsibility is a condition where the obligation to accept or endure the burden for someone as a result of his own attitude or because of other parties for what he has been obliged to do (Sukma, 2016., Yuyut, 2018)ํ․․ In dimensions of responsibility philosophy, responsibility consequences of a someone's freedom due to his actions that are moral and ethical (Bertens, 1983) ${ }^{2}$. Responsibility and freedom are inseparable because a responsible person is a person whose actions are done freely or without pressure to act and make decisions. Related to this discussion, the government has responsibility for the obligations mandated by 1945 Constitution to regulate and organize public services.

Article 1 section (1) of Law Number 25 of 2009 concerning Public Services define:

"The Public Services is an activity in order to fulfill the service needs in accordance with laws and regulations for each citizen for goods, services and/or administrative services provided by public service provider."

Therefore, the public service provider is any state administering institution, corporations and independent institution established under the laws and regulations for public service activities and other legal entities established solely for public service activities $^{3}$. The officials, officers, employees and everyone who works in an organizing organization has the obligation to undertake actions that support the public services ${ }^{4}$. The critical point that should be reflected on is the problem of individuals or people who are responsible for actions that are assumed to have freedom. On the other hand, public officials must place freedom in actions in the corridor of public services implementation.

In accordance with the 1945 Constitution, there are "state obligations" and "the government duty" to protect and serve all public interest. In this regard, the government needs to act in order to embody the optimal service function. Each government action must be based on limited authority provided by law, otherwise known as the legality principle.

Thus, not all the citizen's needs that are served have laws and regulations. To achieve its goals, the government can provide ad hoc services on a discretionary basis or by free authority. Discretion is contained in Article 1 number 9 of Law Number 30 of 2014 concerning the Government Administration which reads:

\footnotetext{
${ }^{1}$ Prayuti, Yuyut. Implementation of Reversal Burden of Proof Principle at Consumer Dispute Settlement Agency (BPSK) as a Legal Protection Effort for Consumers. First International Conference on Technology and Educational Science; Bali, (2018). DOI: 10.4108/eai.21-11-2018.2282274. Sukma, Liya. 2016. "Pertanggung Jawaban Produk (Product Liability) sebagai Salah Satu Alternatif Perlindungan Konsumen", Dialogia Iuridica: Jurnal Hukum Investasi, $7(2)$ : 37.

2 Bertens, K, Etika, Jakarta: PT. Gramedia Pustaka Utama, 1993.

${ }^{3}$ See Article 1 point 2 of the Public Service Law.

${ }^{4}$ See Article 1 poit 5 of the Public Service Law.
} 
"Discretion is a decision and/or action determined and/or carried out by the government officials to solve concrete problems in government administration in terms of laws and regulations that provide choices, not regulated, incomplete and/or government stagnation."

According to Indroharto ${ }^{5}$, free authority or discretion occurs when the government or state administration is given the scope of freedom to determine the decision contents that will be issued. The changing needs of the community require the government to move quickly and actively realize the maximum public services. It is not easy to account for future developments in the community's needs through laws and regulations. As such, the use of discretion as a public service instrument provides space for more flexible and appropriate responses from the government. The second critical point, that must be seen sociologically, is that public services must be represented by responsive public officials ${ }^{6}$. Especially in relation to how discretion can address previously inaccessibile problems. Notwishstanding, discretionary regulations must not conflict with the existing government regulations.

In accordance with Article 22 of the AP Law, discretion can only be appealed to by an authorized official and the use of each discretion by government officials aims to: a) facilitate the government's administration; b) fill a legal vacuum; c) provide legal certainty; and d) resolve government stagnation in certain conditions for the benefit of public interest. Government officials who use discretion must meet the following requirements: a) in accordance with discretion goals as referred in Article 22 section (2); b) it does not contradict with existing laws and regulations; c) in accordance with general principles of good governance; d) based on the objective reasons; e) not attract conflict of interest; f) it is done with good intention? ${ }^{7}$.

Based on the geen bevoegdheid zonder verantwoordelijkheid principle, which means no authority and responsibility. There are two terms related to responsibility, namely responsibility and liability. According to Tatiek Sri Djatmiati, 'responsibility' is a form of responsible politics by government to the parliament that consists of collective and individual responsibility. On the other hand, 'liability' is an accountability addressed to the government or the state, which means that they are required to pay compensation if their actions result in material or mental loss, directly or indirectly to its citizen ${ }^{8}$. Responsibility is needed to ensure legal protection for citizens from the abuse of power by the government and to regulate government authority, so that people whose rights have been violated can provide resistance to a government that harms the public interest.

\footnotetext{
${ }^{5}$ Indroharto. Usaha Memahami Undang-Undang tentang Peradilan Tata Usaha Negara, Buku I. (Jakarta: Pustaka Sinar Harapan, 1993), page 99-101.

${ }^{6}$ Campbell, E. (1999). 'Towards a Sociological Theory of Discretion'. International Journal of the Sociology of Law, 27; 79-101. https://doi.org/10.1006/ijsl.1999.0082

${ }^{7}$ See Article 24 of AP Law

${ }^{8}$ Tatiek Sri Djatmiati, "Perizinan sebagai Instrumen Yuridis dalam Pelayanan Publik", Orasi Pengukuhan Guru Besar Hukum Administrasi Fakultas Hukum Universitas Airlangga Surabaya, 24 November 2007, page 17-18.
} 
There are two binding entities in government's administration, they can be differentiated as the position and office holder. A position is formed and is given to an institution in public with its own work scope which are attached to authority, tasks, and functions ${ }^{9}$. While the office holder is a functionary position who acts for, and on behalf of, the position that carries out authority, tasks, and functions attached to said position ${ }^{10}$. Related to these two entities, there are two norms, known as government norms (bestuurnorm) and official behavior norms (gedragsnorm) ${ }^{11}$ An official must pay attention to and obey both norms in order to use their authority. Their actions must be consistent with legal norms and not violate the rights of the. In the use of authority, there are times when officials may be influenced by various factors that allow irregularities. If there are any irregularities from that authority, the consequence is responsibility.

In principle, the government's obligation to endure responsibility is a return function before violation of the law. However, if the return fails, the government is liable to be burdened with the obligation to compensate as the consequence. Based on the description above, there are a number of responsibilities in the administration of public services, including job and personal responsibilities. Therefore, this article discusses issues with the sociological dimension of constitutional law to emphasize how public officials carry out their functions and powers. Although the discussion in this article interprets the existing regulation in Indonesia, it is intended to provide broader insights into a whole range of constitutional problems.

\section{INTERPRETATION OF RESPONSIBILITY ISSUES: BETWEEN STRUCTURAL POSITION AND PERSONAL MATTERS}

A. Conceptualization of Job Responsibility Issues

A government official who takes action to implement the authority, for whom the responsibility of the position shall be borne. The job responsibilities relate to the principle of legality of governmental acts. The principle of legality contains three components: procedure, authority, and substance. If the three components of legality are not fulfilled, it will cause a juridical flaw in the act of government ${ }^{12}$. The problems of legality in governmental acts of administrative law relates to the approach to government power. The principle of legality functions as a government norm (bestuurnorm). This refers to a series of written and unwritten rules that are legally applicable and applied to government positions. It ensures that the use of powers must be a lawful act, according to law. If the use of powers is an illegal act, the office holders are held accountable.

\footnotetext{
${ }^{9}$ Ridwan. Diskresi dan Tanggung Jawab. (Yogyakarta: UII Press, 2014), page 27.

${ }^{10}$ Ibid., page 28.

${ }^{11}$ Ibid., page 190.

${ }^{12}$ Philpus M. Hadjon. Op. Cit., page 2.
} 
Job responsibility brings consequences related to civil liability and state administration. State administration accountability is a position accountability, while civil liability can become a position accountability if related to the illegal acts by authorities (onrechtmatige overheidsdaad) ${ }^{13}$.

The illegal act (onrechtmatigedaad) can be seen in Article 1365 of Civil Code which states that each illegal act, and because the harm it brings to others, compensation is required for the losses incurred.

While the terms onrechtmatige overheidsdaad were mentioned in Supreme Court Circular Letter Number 4 of 2016 which states that an illegal act by the government is an illegal act which is conducted by the government power holders. This is also commonly known as onrechtmatige overheidsdaad (OOD).

The OOD lawsuit relates to job responsibilities, the basis of the lawsuit is Factual Action that Harms the People ${ }^{14}$. The Factual Action (feitelijkehandeling) is action taken by officials, in their position as official (faute de service). According to Philip M. Hadjon, the definition of feitelijke handeling is actions that do not result in legal consequences. However, it is possible for a citizen or private legal entity to suffer losses related to feitelijke handeling from an effort made by the state administration. Sometimes, the feitelijke handeling is onrechtmatige overheidsdaad if the elements are fulfilled ${ }^{15}$. While faute de service occurs if there is an error related to services in the use of its authorities ${ }^{16}$, the defendant is a position carried out by the government as a public legal entity.

The OOD was filed to the State Administration Judiciary, as described in the fifth paragraph of the general explanation of the AP Law. That is, a citizen can file a lawsuit to the State Administration Judiciary against decree and / or entities act and / or government officials, because the AP Law is also a material law from the State Administration Judiciary system.

Given that the object of the State Administration Judiciary dispute is the State Administration decree, hereby Article 87 of AP Law states that with the enactment of AP Law, the meaning of State Administration decree, which was previously regulated in Administrative Court Law, changes to a written stipulation which also includes factual action. It is final and in a broad sense based on the provisions of laws and regulations and AUPB. It is an entities decree and / or state administration officials in the environment of executive, legislative, judiciary and other state administration who have the potential of legal consequences and / or applied to citizens.

\footnotetext{
${ }^{13}$ Ibid., page 1.

${ }^{14}$ Muhammad Adiguna Bimasakti, "Onrechtmatige Overheidsdaad oleh Pemerintah dari Sudut Pandang UndangUndang Administrasi Pemerintahan", Jurnal Hukum Peratun, Volume 1 Nomor 2, August 2018: 265-286, page 277.

${ }^{15}$ Philipus M. Hadjon, et al., Pengantar Hukum Administrasi Negara. (Yogyakarta: Liberty University Press, 1993), page 177.

${ }^{16}$ Yudhi Setiawan, et al., Hukum Administrasi Pemerintahan: Teori dan Praktik (Dilengkapi dengan Beberapa Kasus Pertanahan. (Jakarta: Rajawali Pers, 2017), page 206-207.
} 
In line with the Supreme Court that stated in SEMA Number 4 of 2016, the lawsuit object in State Administration Judiciary includes written determination and / or factual actions ${ }^{17}$. The OOD dispute is automatically a state administration dispute or administrative dispute. As such, the authority that tries this OOD is the authority of the State Administration Judiciary. In connection with Factual Action that Harms the People, the OOD lawsuit was filed to states that Factual Action by government officials is illegal and the plaintiff is entitled to compensation. Therefore, the elements that contain illegal acts in Article 1365 of the Civil Code are used, namely: a) there is an act; b) the act is illegal; c) there is a loss; d) there is a mistake; and e) there is causality between the illegal act and the losses incurred. The five elements are cumulative. Thus, if an element is not fulfilled, a person cannot be subject to the Illegal Act article.

Any illegal act committed by the government (onrechtmatige overheidsdaad) rises the right to sue for the losses party and the party who bears the responsibility is the government legal entity. The government legal entities are held accountable for what their officials do, which in their position have carried out their actions in accordance with the formal environment of the authority or task assigned to them.

Job responsibility is held to the officials if the use of their authority is not lawful or contrary to the applicable legal principles. Related to the authority, a government official has free authority, namely discretion. Sometimes, discretion in the form policy regulations can be contrary to the applicable legal principles.

The case that occured in Jember is an example of how discretion can become a policy that contrasts with the existing rules. Where thirty Changes to Regent Regulations concerning position, organizational structure, and working procedure of Jember Regency Government that signed on January 3, 2019. The problem is related to the thirty Changes to Regent Regulations concerning the position, organizational structure, and working procedure without going through a consultation process with the East Java Government and not preceded by job analysis process. This results in overlapping job descriptions among regional apparatus organizations. It is contrary with Government Regulations Number 18 of 2016 concerning Regional Apparatus and Ministry of Internal Affairs Regulation Number 35 of 2012 concerning Job Analysis in Ministry of Internal Affairs and Regional Government environment. It is mentioned in the Ministry of Internal Affairs Regulation that a Regent / Mayor report the results of job analysis to the Governor with a copy to the Minister of Home Affairs through the General Secretary for evaluation. The Government Regulations also mentioned that the guidance to filling positions in regional apparatus are carried out on a merit-based system..$^{18}$ If, in the form of Regent Regulations concerning the position, organizational structure and working procedures are not carrying out the process according to the

\footnotetext{
${ }^{17}$ See the explanation about lawsuit object in SEMA Number 4 of 2016 page 13 letter A number 1.

${ }^{18}$ Merit system is a policy and state civil apparatus management based on qualification, competence and performance fairly without discriminating against political background, race, color, religion, origin, gender, marital status, age, or disability. See Article 1 Number 22 of State Civil Apparatus Law.
} 
Law and Regulations, it constitutes a violation of the Government Regulations Number 18 of 2018 and Ministry of Internal Affairs Regulation Number 35 of 2012.

The Regent policy relates to the position, organizational structure, and working procedures violating the provision of the AP Law regarding the terms of using discretion as stated in the provisions of Article 24 of the AP Law. From the provision of Article 24 letter $C$ states that the discretion according to AUPB. According to Article 10 section (1) of the AP Law, what is meant by AUPB includes the principles: a. legal certainty; b. expediency; c. impartially; d. accuracy; e. non-abuse of authority; $f$. openness; g. public interest; and h. good services. If observed, according to the Regent Regulations concerning the position, organizational structure and working procedure issued by the Regent of Jember, there had been inaccuracies in making administrative decisions. So that the Regent Regulations cannot be implemented immediately and can be canceled because it contradicts several principles in the AUPB, including the principle of legal certainty and the principle of accuracy.

\section{B. Personal Responsibility}

Personal responsibility relates to functional, behavioral or official behavioral norms (gedragsnorm) in administrative law. Government officials, as governmental entity, carry out legal actions based on authority. If the use of authority was abused or arbitrary, the authorities responsible are held accountable. Logemann said, "the position is represented by the official. This means not only accountability for occupational actions that implemented, but also psychic elements such as bad intentions, error and knowledge. Therefore, there is lawsuit in their personal behavior both themselves and their family and their social dignity. The important aspect of an official's personal responsibility is oath of office as an oath of loyalty." ${ }^{19}$

An official who is given orders should do their duty in accordance with their authority. However, given that an official is only a human being, with a spiritual and physical nature, there is a necessarily subjective element or personal interest factor in using ones authority to carry out particular actions. As such, there is potential for the deviation of authority. If an official takes legal action because of his negligence, he must be responsible for its consequences. The exercise of authority for purposes other than those stipulated by law, is prohibited and considered an abuse of authority.

The abuse of authority (detournement de pouvoir), according to Sjachran Basah, is an action that extends the use of authority beyond the intended purposes as set out by the regulations on which the authority is given and it causes harm to the affected party. In other words, the act is for personal benefit or the benefit of their group. ${ }^{20}$ The concept of detournement de pouvoir is one of the AUPB principles, namely the principle of prohibiting abuse of authority.

\footnotetext{
${ }^{19}$ Ridwan. Diskresi... Op. Cit., page 193-194.

${ }^{20}$ Sjachran Basah. Eksistensi dan Tolok Ukur Badan Peradilan Administrasi di Indonesia. (Bandung: Alumni, 1985), page 245.
} 
Abuse of authority is only possible when carried out by officials who obtain authority through attribution and delegation. Related to the authority obtained through the mandate, the possibility party that abuse the authority is the one who gives the task (mandans) not those who carry out the duty (mandataris). The assignor or mandans possesses the authority and legal responsibility to abuse authority. It is not possible for the mandataris to abuse the authority because they do not have authorities and are therefore not burdened with that responsibility.

The detournement de pouvoir, is also understood as an action being beyond authority or not authorized. According to F.R. Bohtlingk, this referred to an official who is not authorized to act on behalf of the position. In other words, the position is not given to him according to law, he was neither appointed nor elected, or appointed by unauthorized person, there is legal flaw in the appointment decision, the appointment has not been made, he is on suspension or he has been fired, etc. Everything that is done by an unauthorized official is not an act of office. ${ }^{21}$

Therefore, an official can be burdened with responsibility and personal accountability for his actions. An official who represents the government legal entities cannot be denied his personal responsibility if he acts carelessly, with bad intentions, or is morally deplorable. Personal responsibility is burdened to an official if there is an element of maladministration in the government administration in the form of power abuse. Civil and criminal compensation is required to alleviate the related harms incurred.

One example of personal responsibility as a result of the power abuse was the case that befall Tengku Azmun. Tengku Azmun was a public official, in this case as a Regen of Pelalawan Regency, who became a suspect in a criminal case of corruption in the Bhakti Praja office project. The legal case started from the purchase of 110 hectares of land area by the Pelalawan Regency Government that will be used for government office land known as Bhakti Praja. In 2002, the land purchase was paid by Pelalawan Regency Government, but the land acquisition for the same project was re-conducted and budgeted in the APBD of 2007, 2008, 2009 and 2011.

The land purchase was not recorded as an asset of Regional Government in accordance with Attachment 2 letter C Kepmendagri Number 11 of 2011 concerning Guidelines for Regional Goods Management and Article 1 number 16 of Government Regulations Number 105 of 2000 concerning Management and Regional Financial Accountability. As a result, there was a state loss of 38 billion rupiahs. Further, it was proved that Tengku Azmun received the funds by staging 16 billion rupiahs. Based on the case that ensnared Tengku Azmun, it can be said that Azmun is not guided by AUPB. In addition, there was maladministration elements in the form of power abuse that led to his conviction of eighteen months in prison in 2018.

${ }^{21}$ Ridwan. Diskresi... Op. Cit., page 175. 


\section{LEGAL CONSEQUENCES OF MALADMINISTRATION IN PUBLIC SERVICES}

In order to fulfill the public interest, the government has organized public services. However, a government official who is given task or authority to provide public services did not implement his duty carefully in accordance with the provision of laws and regulations and AUPB. It is often found that the quality of public services is poor and cannot satisfied the community.

The services are less responsive, inefficient, ineffective, illegal charges, prolonged delays, long and complicated bureaucracy, the habit of public officials who always ask to be served instead of serving breeds laziness in government offices. This often results in officials committing illegal acts to cut corners in their responsibilities. These situations can also be utilized by public service providers to pursue their personal interests.

The main problem that occurs in the administration of public services is the performance orientation of public services. The orientation of public service administration should be based on public interest or community needs. This orientation creates a bureaucratic culture. The bureaucratic culture in services has been a long disease. It is the habit of bureaucrats who ask to be served instead of serving. This condition is the main element of maladministration.

The word maladministration comes from the Latin "mal" in "malum" which means bad and "administration" is from "administrare" which means to serve. Thus, the meaning of maladministration is bad service. From this understanding, it can be said that maladministration is related to public officials bad habits in the service process. ${ }^{22}$

The definition of maladministration contained in Article 1 Number 3 of Constitution Number 37 of 2008 concerning Ombudsman of Republic of Indonesia reads:

"Maladministration is an illegal act, beyond authority, using authority for other purposes, including the negligence and ignorance of law in public service administration that conducted by the State Administrators and government which causes material and / or immaterial loss to community and individuals."

Although maladministration is illegal in public services, the word maladministration is not explicitly found in Public Service Law. The Public Service Law only mentioned obligation and prohibition for public service administrator. ${ }^{23}$ The Public Service Law also stipulates the obligation to behave for the implementers in organize the public. ${ }^{24}$

Put simply, maladministration is any public service that does not align with administrative ethics, procedures and provisions of the applicable laws and regulations. ${ }^{25}$ However, of course we must pay attention to which legal basis is violated,

\footnotetext{
${ }^{22}$ Yudhi Setiawan, et al. Op. Cit, page 69.

${ }^{23}$ See Article 14, 15, 16 and 17 of Public Service Law.

${ }^{24}$ See Article 34 of Public Service Law.

${ }^{25}$ Hendra Nurtjahjo, et al. Memahami Maladministrasi. (Jakarta: Ombudsman Republik Indonesia, 2013), page 11 .
} 
facts, evidences, witnesses or related parties and the extent to which incident is against the applicable law and AUPB.

In government administration, each administrator and implementer in using their authority must comply with laws, regulations and $\mathrm{AUPB}^{26}$, especially the principle of not abusing power. The principle of not abusing power is a principle which requires that the use of authority by government officials and / or agencies does not pursue purposes other than that required by the granting of this authority to them. ${ }^{27}$ The principle is realized in Article 17 of the AP Law which regulates the prohibition of power abuse by officials and / or government agencies which include: a) prohibition to beyond authority, b) prohibition to jumble of power and / or c) prohibition to act arbitrarily.

Article 19 regulates the legal consequences of a decision or action that fulfills the prohibition to beyond authority and prohibition to act arbitrarily is that the decision or action is illegal, while those who fulfill the prohibition to jumble of power will result in the cancellation of the decision or action. Article 70 section (2) regulates the illegal decision or action that may result in the non-binding of the decision or action and it will be considered that there have never been any legal consequences caused.

If government officials in the use of government authority abuse their power (detournement de pouvoir) and act arbitrarily (abuse de droit), there is maladministration element and, of course, there are illegal acts. The responsibility of that act is burdened to the official who commits it. According to Indroyanto Seno Adji power abuse can be realized in the following 3 meanings:

a. The power abuse in the sense of taking action contrary to the public interest or aims to benefit the interest of oneself or group;

b. The power abuse in the sense of official's action that aims to fulfil public interests, but still violates the purpose of the given authority;

c. The power abuse in the sense of perversion of procedures that use other procedure so that the goals can be achieved..$^{28}$

According to Seno Adji, in the framework of state administrative law, the power abuse and act are arbitrary parameters that limit the discretionary freedom of the state apparatus. Regarding the suspicion of power abuse, the court which has authority to give an assessment whether there is power abuse or not against actions taken by the government agencies / officials is the State Administration Judiciary. ${ }^{29}$ In Perma Number 4 of 2015 concerning Guidelines for judging the element of Power Abuse in Article 2 section (2) states that the new Court has the authority to accept, examine, and decide on the application assessment whether or not there is an element of power abuse after the results of supervision from the government internal control apparatus or APIP.

\footnotetext{
${ }^{26}$ See Article 10 section (1) of AP Law.

${ }^{27}$ See the explanation of Article 10 section (1) letter E of AP Law.

${ }^{28}$ Ridwan. Diskresi...Op. Cit., page 177.

${ }^{29}$ See Article 21 and 87 of AP Law.
} 
Based on Article 20 of AP Law, the supervision against the prohibition of power abuse was conducted by APIP. Regarding the allegation of power abuse, the results of APIP supervision include: a) there are no errors; b) there are administrative errors; c) or there are administrative errors that lose state finances. If there is an administrative error under APIP supervision, it is followed up by completing the administrative in accordance with laws and regulations. However, if there is administrative error under APIP supervision that lost state finances, it will be followed up by returning the losses to the state. If the administrative error that occurs is not caused by an element of power abuse, the burden of returning state losses is borne by government agencies. If the administrative error occurs because there is an element of power abuse, the burden of returning the state losses is borne by the officials. ${ }^{30}$

According to Government Regulations Number 60 of 2008 concerning Government Internal Control System in section (2) stated that APIP in carrying out its internal control duties need to go through several stages as follows: (a) audit, (b) review, (c) evaluation, (d) monitoring and (e) other surveillance activities. In Article 16 of Government Regulations Number 12 of 2017 concerning Guidance and Supervision of Regional Government Administration regulates the implementation principles of supervision by APIP, namely: A) professionality; b) independent; c) objective; d) there is no overlap between APIPs; and e) early warning oriented. APIP as referred to Article 48 of Government Regulations Number 60 of 2008 is contained in Article 49 section (2) which consists of: a) BPKP; b) General Inspectorate or other names that functionally implement internal supervision; c) Province Inspectorate; and d) Regency / City Inspectorate.

The follow up guidance and supervision by APIP requires coordination with law enforcement officers that are adjusted to the respective authorities and functions between APIP and law enforcement officers (police and prosecutors). If in the results show evidence of administrative irregularities, the next process is carried out by APIP, in accordance with the provisions of Government Regulations and laws and regulations that regulate government administration. Meanwhile, if preliminary evidence is found that there is criminal element in the deviation, the next process is submitted to and carried out in accordance with the provisions of laws and regulations by law enforcement officials.

If there is an administrative error in the results of APIP supervision that causes loss to the state finances, it will be followed up by returning the losses to the state finances. In administrative law, the terminology used is based on the formulation of Article 1 Number 22 of Law Number 1 of 2004 concerning the State Treasury, namely:

"The State / Regional loss is lack of money, securities and goods, that are real and the amount is definite as a result of illegal act, whether deliberate or negligent."

Thus, in the laws and regulations it was explained that the state / regional loss caused by illegal acts or personal negligence must be replaced by the guilty party. The settlement for these losses is the recovery of the state / regional from the losses that

${ }^{30}$ See Article 20 section (3), (4), (5) and (6) of AP Law. 
have been incurred. The Audit Board of the Republic of Indonesia (BPK) determines the compensation for the treasurer. While the determination of compensation by civil servants who are not treasurers is determined by the minister / head of institution / governor / regent / mayor. If the determined parties whose compensation are proven to have committed administrative and / or criminal violations, they may be subject to administrative and / or criminal sanctions.

There are 3 categories of administrative sanctions in AP Law. First, light administrative sanctions in the form of verbal or written warnings, or postponement of promotion, class and / or rights attached to the position. Those sanctions are directly applicable, but with consideration of the elements of justice and proportionality. Second, moderate administrative sanctions in the form payment of forced money and / or compensation, temporary dismissal with or without obtaining office rights. Third, heavy administrative sanctions in the form of permanent dismissal, with or without obtaining financial rights, and other facilities also announced in the media. The second and third sanctions can only be sought after the internal inspection process.

Regarding the case of 30 changes to Regent Regulations concerning position, organizational structure and working procedure of Jember Regency Government which did not through a consultation process with the East Java Government and was not preceded by a job analysis process. There was a maladministration element related to the violation of laws and regulations and procedural deviation and had violated the AUPB. If observed, the Regent can be subject to administrative sanctions because he has committed administrative violations against the laws and regulations using discretion. The types of administrative sanctions that can be subjected on the Regent of Jember are moderate or heavy administrative sanctions, because the case has thorough internal inspection processes, which means that the Regent has been proven to have committed administrative violations as well as the previous administrative violations, or has committed several consecutive violations for a short period of time.

In connection with power abuse conducted by government officials, several administrative law experts stated that government officials, either with discretion or beleid, cannot fall into the criminal scope. Regarding administrative irregularities, it falls within the scope of state administrative law and cannot be assessed within the scope of criminal law. In line with what is meant by the provisions in Article 2 section (1) Perma Number 4 of 2015 which states that

"The court has the authority to accept, examine and decide on the application assessment whether or not there is an element of power abuse in decisions and / or actions of government officials before the existence of a criminal process."

The article formulation gives the impression that administrative judicial process in this case the authority of State Administration Judiciary, takes precedence before the criminal judicial process.

From an administrative point of view, government officials have been attached to public authority. Thus, if a government official is considered to have violated their authority, administrative solutions would be sought first. As in the case of Regent of 
Jember, the administrative sanctions were evident with the issuance of the Governor of East Java Decree number: 700/1713/060/2020.

If the action or decision of an official results in criminal law, civil losses, corruption, collusion and nepotism which causes losses to the state or regional finances it is the personal responsibility of an official and the state cannot endure the burden. This does not erase the obligation of the maladministrator to settle administratively. As in the corruption case by the former Regent of Pelalawan, Tengku Azmun, there was a maladministration element in the form of power abuse. As a result of his corruption, he was burdened with personal responsibility in the form of punishment and administratively he was permanently dismissed from his position as Reagan of Pelalawan.

The decisions made by individuals as public officials, although they have legal consequences, are not necessarily seen as a mere moral and ethical dimension. After a period of detention, Tengku Azmun still has citizenship rights, and has shown political support for the regent candidate. Regardless of whether the candidate supported by him will win the election and become regent or not, it is interesting to see how the masses attach to the individual and how illegal acts do not necessarily emphasize the existence of ideal common sense.

In the case of Jember Regent, the legal consequences that follow actions considered maladministration precisely emphasize the existence of the intertwined issues of law and politics. In this context, the personal decision of Jember Regent to run as an individual candidate or a non-party candidate intersects with dimensions of law enforcement. The political dynamics, which seem to have autonomy and speak in the sense of democracy, precisely intersect with legal issues. This unfortunately translates into how power plays into law.

\section{CONCLUSION}

Based on the discussion above, the following conclusions have been made:

(1) There are two forms of responsibility of government officials in carrying out public services, namely job responsibility and personal responsibility. If a government official acts for and on behalf of the position or commits an act within the environment of his formal authority, responsibility is burdened to the position. On the other hand, if a government official representing legal entities acts very recklessly, with bad intention, and morally deplorably, responsibility is burdened to the individual. (2) The legal consequences for government officials who commit maladministration in public services can become the job responsibility if the administrative scope leads to administrative or procedural implementation or within the environment of formal authority.

Government officials have been attached to public authority. As such, if a government official is considered to have violated their authority, administrative solutions are sought first. If the action or decision of an official results in criminal law, civil losses, corruption, collusion and nepotism which causes losses to state or regional 
finances, the personal responsibility of an official and the state cannot endure the burden. This does not erase the obligation of the maladministrator to settle administratively.

The conceptualization discretionary actions or the use of personal authority is central to how regulations and legal rules can be interpreted personally. This understanding becomes a space within which to see the dimensions and social contexts represented by public officials in determining an action. Therefore, the multiplicity both culturally or through political perspectives of a public policy can enrich legal analysis.

\section{ACKNOWLEDGMENT \\ None \\ COMPETING INTEREST \\ None}

\section{REFERENCES}

\section{A. Books}

Basah, S. (1985). Eksistensi dan Tolok Ukur Badan Peradilan Administrasi di Indonesia. [Existence and Benchmarks of Administrative Courts in Indonesia], Alumni.

Hadjon, P. M. (1993). Pengantar Hukum Administrasi Negara. [Introduction to State Administrative Law], Liberty University Press.

Indroharto. (1993). Usaha Memahami Undang-Undang tentang Peradilan Tata Usaha Negara (Buku I). [Efforts to Understand the Law on State Administrative Courts, Book I], Pustaka Sinar Harapan.

Nurtjahjo, H. (2013). Memahami Maladministrasi. [Understanding Maladministration], Jakarta: Ombudsman Republik Indonesia.

Ridwan. (2014). Diskresi dan Tanggung Jawab. [Discretion and Government Responsibility], UII Press.

Setiawan, Y., Hadiatmodjo, B. D., \& Ropii, I. (2017). Hukum Administrasi Pemerintahan: Teori dan Praktik (Dilengkapi dengan Beberapa Kasus Pertanahan. [Government Administration Law: Theory and Practice (Completed with Several Land Cases)], Rajawali Pers.

\section{B. Laws and Regulations}

Undang-Undang Dasar Negara Republik Indonesia Tahun 1945.

Undang-Undang Nomor 1 Tahun 2004 tentang Perbendaharaan Negara.

Undang-Undang Nomor 37 Tahun 2008 tentang Ombudman Republik Indonesia. 
Undang-Undang Nomor 25 Tahun 2009 tentang Pelayanan Publik.

Undang-Undang Nomor 5 Tahun 2014 tentang Aparatur Sipil Negara.

Undang-Undang Nomor 30 Tahun 2014 tentang Administrasi Pemerintahan.

Peraturan Pemerintah Nomor 60 Tahun 2008 tentang Sistem Pengendalian Intern Pemerintah.

Peraturan Pemerintah Nomor 12 Tahun 2017 tentang Pembinaan dan Pengawasan Penyelenggaraan Pemerintahan Daerah.

Peraturan Mahkamah Agung (Perma) Nomor 4 Tahun 2015 tentang Pedoman Beracara Penilaian unsur Penyalahgunaan Wewenang.

Surat Edaran Mahkamah Agung Nomor 4 Tahun 2016 tentang Pemberlakuan Rumusan Hasil Rapat Pleno Kamar Mahkamah Agung Tahun 2016 Sebagai Pedoman Pelaksanaan Tugas Bagi Pengadilan.

\section{Journals / Papers / Articles}

Bimasakti, M. A. (2018). Onrechtmatige Overheidsdaad oleh Pemerintah dari Sudut Pandang Undang-Undang Administrasi Pemerintahan. [ Onrechtmatige Overheidsdaad by the Government from a Government Administration Law Point of View], Jurnal Hukum Peratun, 1(2), 277.

Campbell, E. (1999). Towards a Sociological Theory of Discretion. International Journal of the Sociology of Law, 27(1), 79-101. https://doi.org/10.1006/ijsl.1999.0082

Djatmiati, T. S. (2007). Perizinan sebagai Instrumen Yuridis dalam Pelayanan Publik. "[ Licensing as a juridical instrument in public services], Orasi Pengukuhan Guru Besar Hukum Administrasi Fakultas Hukum Universitas Airlangga Surabaya, 24 November 2007, $17-18$.

Prayuti, Y. (2019). Implementation of Reversal Burden of Proof Principle at Consumer Dispute Settlement Agency (BPSK) as a Legal Protection Effort for Consumers. Proceedings of the First International Conference on Technology and Educational Science. https://doi.org/10.4108/eai.21-11-2018.2282274

Sukma, L. (2016). Pertanggung Jawaban Produk (Product Liability) sebagai Salah Satu Alternatif Perlindungan Konsumen. [Product Liability as an Alternative for Consumer Protection], Dialogia Iuridica: Jurnal Hukum Investasi, 7(2), 37. 